\title{
PENGARUH KONSENTRASI URINE SAPI DAN PERENDAMAN TERHADAP PERTUMBUHAN SETEK JAMBU AIR KING ROSE (Syzygium aqueum Burn.f.Alston)
}

\section{THE EFFECT OF COW URINE CONSENTRATION AND SOAKING ON THE GROWTH OF KING ROSE WATER APPLE (Syzygium aqueum Burn.f.Alston)}

\author{
Tini Sudartini ${ }^{1}$, Elya Hartini ${ }^{1}$, Lulu Sofia Burhan ${ }^{1}$ \\ ${ }^{1}$ Program Studi Agroteknologi Fakultas Pertanian Universitas Siliwangi \\ Jalan Siliwangi No. 24 Kota Tasikmalaya Kode Pos 46115 Jawa Barat \\ Korespondensi : thinisudartini@unsil.ac.id
}

\begin{abstract}
ABSTRAK
Jambu air diperbanyak dengan setek yang berasal dari hasil pangkasan. Setek perlu dipercepat tumbuhnya dengan perendaman dalam urine sapi yang mengandung ZPT IAA dan IBA. Lama perendaman setek dalam larutan urine sapi disesuaikan dengan konsentrasinya. Penelitian bertujuan untuk mengetahui pengaruh konsentrasi urine sapi dan lama perendaman terhadap pertumbuhan setek jambu air king rose apple (Syzygium aqueum Burn.f.Alston). Percobaan dilaksanakan di Kelurahan Kahuripan Kecamatan Tawang Kota Tasikmalaya, pada bulan Februari sampai April 2020. Penelitian ini menggunakan metode ekperimental, dengan Rancangan Acak Kelompok (RAK) pola faktorial diulang sebanyak dua kali. Faktor pertama adalah konsentrasi urine sapi dengan empat taraf, yaitu $\mathrm{a}_{0}=$ tanpa urine sapi , $\mathrm{a}_{1}=$ konsentrasi urine sapi 30\%, $\mathrm{a}_{2}=$ konsentrasi urine sapi $50 \%$, dan $\mathrm{a}_{3}=$ konsentrasi $70 \%$. Faktor kedua adalah lama perendaman dalam urine sapi terdiri dari empat taraf, yaitu $\mathrm{p}_{0}=$ kontrol), $\mathrm{p}_{1}=60$ menit, $\mathrm{p}_{2}=$ 90 menit, dan $\mathrm{p}_{3}=120$ menit. Data dianalisis menggunakan sidik ragam dengan uji $\mathrm{F}$ dan dilanjut dengan Uji Jarak Berganda Duncan dengan taraf nyata 5\%. Hasil penelitian menunjukkan bahwa terdapat interaksi antara konsentrasi urine sapi dan lama perendaman terhadap jumlah tunas. Perlakuan konsentrasi urine sapi 50\% dengan lama perendaman 60 menit menghasilkan jumlah tunas yang paling banyak. Secara mandiri konsentrasi urine sapi 50\% menghasilkan panjang tunas terpanjang. Konsntrasi urine sapi dan lama perendaman tidak berpengaruh terhadap kecepatan bertunas, luas daun dan panjang akar.
\end{abstract}

Kata kunci : Jambu Air, Perendaman, Urine Sapi

\begin{abstract}
This study aims to obtain cow urine concentration and soaking time on the growth of king rose water apple (Syzygium aqueum). Research has been carried out on Jl. Noenoeng Tisna Saputra RT 01 RW 011 Kahuripan Village Tawang District Tasikmalaya City in February to April 2020. The experimental research method used a 4x4 factorial randomized block design (RBD) repeated twice. The first factor is the concentration of cow urine with four levels, namely $\mathrm{a}_{\mathrm{o}}=$ no cow urine or using water (control), $\mathrm{a}_{1}=30 \%$ cow urine concentration, $\mathrm{a}_{2}=50 \%$ cow urine concentration, and $\mathrm{a}_{3}=70 \%$ concentration. The second factor is the long soaking in cow urine consists of four levels: $\mathrm{p}_{0}=$ without soaking (control), $\mathrm{p}_{1}=$ soaking time of 60 minutes,
\end{abstract}


$\mathrm{p}_{2}=$ soaking time of 90 minutes, and $\mathrm{p}_{3}=120$ minutes soaking time. Data were analyzed using variance with the F test and continued with Duncan's Multiple Range Test with a significance level of 5\%. The results showed that there was an interaction between the concentration of cow urine and soaking time on the number of shoots. Treatment of $50 \%$ cow urine concentration with 60 minutes of immersion resulted in the ?highest number of shoots. Independently the concentration of cow urine 50\% produces the longest shoot length. The concentration of cow urine and soaking time did not affect the speed of sprouting, leaf area, and root length.

Key words : Cow Urine, Rose Water Apple, Soaking

\section{PENDAHULUAN}

Komoditas hortikultura berperan sebagai sumber gizi, penyediaan lapangan pekerjaan dan menunjang kegiatan agrowisata dan agroindustri. Jenis-jenis tanaman hortikultura meliputi tanaman buah-buahan, tanaman bunga dan tanaman sayuran. Salah satu jenis buah-buahan yaitu jambu . Jenis jambu yang sudah banyak dibudidayakan masyarakat Indonesia ialah jambu air.

Menurut Hadi, Widiawati dan Sukarsa (2012), pusat pembudiyaan jambu air berada di Pulau Jawa, khususnya dua jenis jambu air yaitu Syzygium malaccense dan $S$. samarangense. Jambu air unggul yang banyak ditanam masyarakat ada 10 jenis diantaranya yaitu jambu air King Rose (Disperta.madiunkota.go.id, 2021). Jambu air mengandung senyawa kimia dan aktivitas farmakologis, sehingga tanaman ini dapat dimanfaatkan sebagai obat alami untuk diare, sakit kepala dan batuk (Anggrawati dan Ramadhania, 2016).

Jambu air ini menghasilkan buah yang memiliki nilai ekonomis tinggi. Harga jual jambu madu di tingkat petani Rp. 25000.-. UPT. BPSB, 2012 dalam Harahap (2017). Menurut Lim, (2012) dalam Aprilia, Wisanti dan Putri, (2021), dalam $100 \mathrm{~g}$ jambu air mengandung kalori $17 \mathrm{kcal}$, protein $0,8 \mathrm{~g}$, lemak 0,1 g, karbohidrat $3 \mathrm{~g}$, vitamin A setara $1 \mathrm{mg}$ dan vitamin $\mathrm{C} 16,7 \mathrm{~g}$, yang sangat baik untuk meningkatkan energi dan sistem kekebalan tubuh.

Kadar vitamin $\mathrm{C}$ yang cukup tinggi pada buah jambu air tersebut sangat diperlukan untuk menguatkan sistem kekebalan tubuh apalagi pada masa pandemic covid 19. Imbas kondisi pandemi memicu tingginya permintaan masyarakat akan buahan buahan karena meningkatnya konsumsi terhadap buahan seiring dengan tingginya kesadaran masyarakat untuk menjaga kesehatan, juga seiring dengan trend masyarakat untuk membudidayakan buah-buahan di pekarangan rumahnya pada masa pandemi yang berdampak terhadap meningkatkan permintaan akan bibit buah-buahan termasuk jambu air.

Dalam upaya memenuhi permintaan akan konsumsi buah-buahan diperlukan peningkatan produksi. Ketersedian bibit unggul bermutu, sangat erat kaitannya dengan peningkatan produksi tersebut. Menurut Pradani, Rianto, dan Suliswati (2018) perbanyakan tanaman jambu air dengan setek dapat diperoleh dari bagian cabang tanaman, baik dari ujung cabang tersier hingga cabang sekunder. Perbanyakan melalui setek, dapat diperoleh bibit unggul dalam jumlah yang banyak dan dalam waktu yang singkat.

Keuntungan menggunakan setek yaitu tanaman cepat berbuah atau cepat menghasilkan buah dan memiliki sifat genetik yang sama dengan induknya. Akan tetapi menurut Fanesa (2011), perbanyakan tanaman secara vegetatif dengan menggunakan setek batang atau cabang memiliki kelemahan diantaranya akar yang terbentuk jumlahnya sedikit dan pendek. Akar yang pendek akan menyebabkan 
penyerapan air, unsur hara dan volume kontak dengan akar lebih rendah dan rentan terhadap pengaruh lingkungan.

Setek dapat didorong untuk membentuk akar lebih cepat dengan aplikasi ZPT Auksin. Auksin yang dapat digunakan berupa auksin alami dan auksin sintetik, salah satu sumber yang mengandung auksin alami yaitu urine sapi. Urine sapi merupakan salah satu substrat organik yang mengandung auksin dan giberelin (Mulyani, Fatmawaty, dan Ritawati, 2018). Urine sapi mengandung nitrogen $(\mathrm{N}) 1,4 \%$; fosfor $(\mathrm{P})$ 0,6\% ; kalium (K) 1,6\%; ZPT IAA $1852 \mathrm{mg}$ $\mathrm{L}^{-1}$ dan GA $291 \mathrm{mg} \mathrm{L}^{-1}$.

Salah satu upaya untuk mempercepat pembentukan dan pertumbuhan akar pada setek dapat dilakukan dengan cara merendam setek dalam larutan urine sapi (Gaol, Kaunang, dan Dompas, 2017). Hasil penelitian Yunanda et al. (2015) diketahui bahwa perendaman stek buah naga dalam larutan urine sapi dengan konsentrasi 50\% berpengaruh baik terhadap waktu muncul tunas, jumlah akar, panjang akar, volume akar, bobot segar dan bobot kering bibit tanaman buah naga.

Menurut Rebin (2013) setiap kali pemangkasan dapat dihasilkan brangkasan basah yang terdiri atas cabang sekunder, tersier, serta daun yang jumlahnya cukup banyak. Untuk pohon jambu air yang berumur sekitar 10 tahun dapat dihasilkan brangkasan basah seberat kurang lebih 90 $\mathrm{kg} /$ pohon. Dari brangkasan tersebut dapat menghasilkan cabang yang terdiri dari cabang sekunder dan tersier (dengan panjang setek $25 \mathrm{~cm}$ ) sebanyak kurang lebih 450 setek/pohon yang dapat digunakan sebagai setek cabang. Setek jambu air tersebut pada umumnya sudah berkayu setengah berkayu. Pada jaringan yang berkayu memiliki dinding sel yang tebal yang dapat menghalangi penyerapan cairan, sehingga perlu perendaman lebih lama agar cairan bisa terserap ke dalamnya.
Menurut Widianto (2002), pada setek yang berasal dari bagian tanaman tua akan lebih sulit berakar disebabkan oleh umur tanaman semakin tua maka terjadi peningkatan zat-zat penghambat perakaran dan penurunan senyawa fenolik yang berperan sebagai auksin kofaktor yang mendukung insiasi akar.

Pertumbuhan setek dipengaruhi oleh interaksi faktor dalam dan lingkungan. Faktor dalam terutama meliputi cadangan makanan dalam jaringan setek, dan jenis tanaman. Sedangkan faktor lingkungan yang mempengaruhi keberhasilan penyetekan adalah media perakaran setek (Danu dan Abidin, 2011).

Menurut Dwijoseputro (2001), setek yang dilakukan pencelupan atau perendaman dalam larutan ZPT, memudahkan setek menyerap ZPT. Semakin lama setek berada dalam larutan semakin meningkat larutan dalam setek. Menurut Mulyani dan Ismail (2015), lama perendaman harus disesuaikan dengan konsentrasi larutan yang digunakan. Lamanya setek dalam larutan bertujuan agar penyerapan ZPT berlangsung dengan baik. Keefektifan ZPT untuk mendorong perakaran ditentukan oleh bahan aktif yang terserap oleh setek.

Perendaman setek dalam cairan urine sapi memungkinkan setek menyerap ZPT yang terkandung dalam urin sapi. Perendaman yang lama memungkinkan ZPT terserap lebih banyak. Oleh karena itu lama perendaman harus disesuai dengan konsentrasi larutan, karena pada konsentrasi yang tinggi lebih banyak bahan aktif yang terkandung di dalam larutan tersebut.

Jika konsentrasi terlalu tinggi maka akan dapat merusak setek karena pembelahan sel dan kalus akan berlebih sehingga menghambat tumbuhnya akar, sedangkan bila konsentrasi yang digunakan di bawah optimum maka zat pengatur zpt tidak efektif (Hariani, Suryawaty, dan Arunasi, 2018). 
Lama perendaman setek pada zat pengatur tumbuh mempengaruhi kadar zatzat yang terserap pada setek. Semakin lama setek direndam maka semakin banyak larutan terserap kedalam setek (Santoso, 2017). Kontribusi penelitian ini adalah sebagai sumber informasi terkait dengan pembuatan bibit dari setek batang jambu air khususnya dan setek batang tanaman lain yang berkayu.

\section{BAHAN DAN METODE}

Penelitian dilaksanakan di Kelurahan Kahuripan Kecamatan Tawang Kota Tasikmalaya pada bulan Februari sampai April 2020. Alat yang digunaan dalam penelitian ini adalah polybag ukuran $10 \mathrm{~cm}$ x $18 \mathrm{~cm}$ ), paranet, timbangan analitik, luks meter, termohygrometer, gelas ukur, sprayer, gunting setek, cutter, bambu. Bahan yang digunakan yaitu setek batang jambu dan urine sapi.

Penelitian ini menggunakan Rancangan Acak Kelompok (RAK) pola faktorial yang terdiri dari dua faktor yaitu:

Faktor pertama konsentrasi terdiri dari 4 taraf yaitu :

$\mathrm{a}_{0}=$ Tanpa urine sapi atau menggunakan air (kontrol)

$a_{1}=$ Konsentrasi urine sapi $30 \%$

$\mathrm{a}_{2}=$ Konsentrasi urine sapi 50\%

$\mathrm{a}_{3}=$ Konsentrasi urine sapi $70 \%$

Faktor kedua lama perendaman yang terdiri dari 4 taraf yaitu :

$\mathrm{p}_{0=}$ Hanya dicelupkan tanpa direndam

(kontrol)

$\mathrm{p}_{1}=$ Lama perendaman 60 menit

$\mathrm{p}_{2}=$ Lama perendaman 90 menit

$\mathrm{p}_{3}=$ Lama perendaman 120 menit

Percobaan ini terdiri dari 16 kombinasi perlakuan, masing- masing perlakuan diulangi sebanyak 2 kali sehingga berjumlah 32 unit perlakuan. Kombinasi Perlakuan dicantumkan pada Tabel 1 berikut ini.
Tabel 1 Kombinasi Perlakuan Konsentrasi Urine Sapi dan Lama Perendaman

\begin{tabular}{lcccc}
\hline Konsentrasi & \multicolumn{4}{c}{ Lama Perendaman (menit) } \\
\cline { 2 - 5 } Urin Sapi & $\mathrm{p}_{0}$ & $\mathrm{p}_{1}$ & $\mathrm{p}_{2}$ & $\mathrm{p}_{3}$ \\
$(\%)$ & $(0)$ & $(60)$ & $(90)$ & $(120)$ \\
\hline $\mathrm{a}_{0}(0)$ & $\mathrm{p}_{0} \mathrm{a}_{0}$ & $\mathrm{p}_{1} \mathrm{a}_{0}$ & $\mathrm{p}_{2} \mathrm{a}_{0}$ & $\mathrm{p}_{3} \mathrm{a}_{0}$ \\
$\mathrm{a}_{1}(30)$ & $\mathrm{p}_{0} \mathrm{a}_{1}$ & $\mathrm{p}_{1} \mathrm{a}_{1}$ & $\mathrm{p}_{2} \mathrm{a}_{1}$ & $\mathrm{p}_{3} \mathrm{a}_{1}$ \\
$\mathrm{a}_{2}(50)$ & $\mathrm{p}_{0} \mathrm{a}_{2}$ & $\mathrm{p}_{1} \mathrm{a}_{2}$ & $\mathrm{p}_{2} \mathrm{a}_{2}$ & $\mathrm{p}_{3} \mathrm{a}_{2}$ \\
$\mathrm{a}_{3}(70)$ & $\mathrm{p}_{0} \mathrm{a}_{3}$ & $\mathrm{P}_{1} \mathrm{a}_{3}$ & $\mathrm{p}_{2} \mathrm{a}_{3}$ & $\mathrm{p}_{3} \mathrm{a}_{3}$ \\
\hline
\end{tabular}

Variabel respon yang diamati yaitu: kcepatan bertunas, jumlah tunas, panjang tunas, luas daun, panjang akar dan volume akar. Data dianalisis dengan analisis ragam taraf nyata $5 \%$. Jika hasil uji $\mathrm{F}$ berbeda nyata dilanjutkan dengan uji jarak berganda Duncan pada taraf nyata $5 \%$.

Setek batang diambil dari tanaman induk yang sudah pernah menghasilkan buah berumur lebih dari 5 tahun, dari Balai Penelitian Pengembangan Benih Hortikultura dan Aneka Tanaman di JL. Raya Jatinangor, Pasir Banteng, Kecamatan Jatinangor, Kabupaten Sumedang.

Media tanam yang digunakan yaitu campuran antara tanah, pasir dan pupuk kandang dengan perbandingan 2:1:1. Media tanam yang sudah dicampur seberat $450 \mathrm{~g}$ dimasukan dalam polybag kemudian disimpan di bawah sungkup plastik transparan yang berbentuk setengah lingkaran, Sungkup kemudian dinaungi dengan paranet $65 \%$. Urine sapi segar diambil pagi hari, diwadahi dalam botol tertutup didiamkan selama $12 \mathrm{jam}$. Urine sapi dilarutkan dalam air sesuai dengan konsentrasi yang dicoba sebanyak $1 \mathrm{~L}$ setiap unit perlakuan. Setek batang direndam dalam larutan urine sapi dengan lama perendaman sesuai dengan perlakuan. Selanjutnya setek ditanam dengan serentak pada media tanam. Pemeliharaan selama percobaan meliputi penyiraman, penyinaran 
dan penyiangan gulma. Penyiraman sekalian dilakukan pada waktu sungkup dibuka pada pagi hari dengan sprayer. Sungkup dibuka detiap pagi pukul 08.00 sampai 09.00, setelah itu sungkup ditutup kembali untuk menjaga kelembaban udara agar tetap tinggi. Intensitas penyinaran sekitar $65 \%$ dan penyiangan gulma dilakukan dngan cara mencabut gulma yang tumbuh (manual).

\section{HASIL DAN PEMBAHASAN}

Suhu udara di dalam sungkup selama penelitian pada pagi hari, rata -rata $25,5^{\circ} \mathrm{C}$, siang hari $30,2^{\circ} \mathrm{C}$ dan sore $27,5^{\circ} \mathrm{C}$, dengan kelembababan dalam sungkup rata rata $96 \%$.
Kisaran suhu dan kelembaban selama penelitian ini memenuhi syarat tumbuh untuk perakaran dan pembentukan tunas setek jambu air. Setek batang jambu air mulai bertunas pada 12 hari setelah tanam (hst).

\section{Kecepatan Bertunas}

Tidak terdapat pengaruh interaksi antara konsentrasi urine sapi dengan lama perendaman terhadap kecepatan waktu bertunas setek, demikian pula secara mandiri perlakuan konsentrasi urine sapi dan lama perendaman tidak berpengaruh nyata terhadap kecepatan waktu bertunas setek batang jambu air (Tabel 2)

Tabel 2. Pengaruh konsentrasi dan lama perendaman urine sapi terhadap kecepatan bertunas stek jambu air

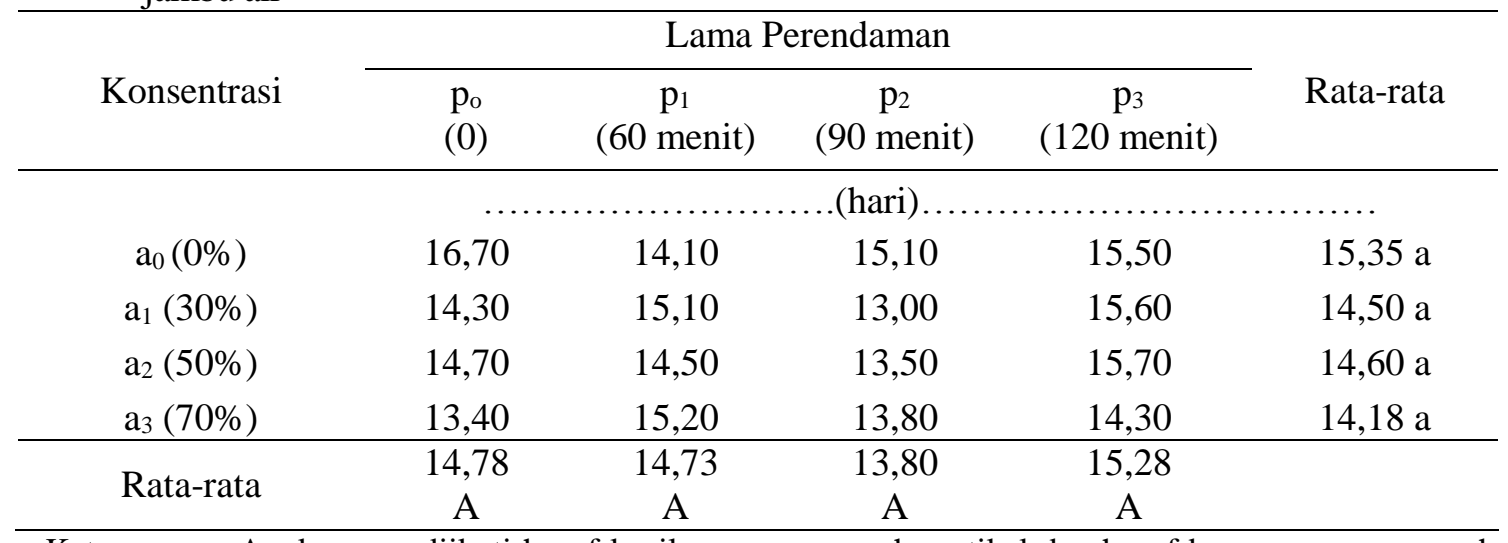

Keterangan : Angka yang diikuti huruf kecil yang sama arah vertikal dan huruf besar yang sama arah horizontal menunjukan berbeda tidak nyata menurut uji Jarak Berganda Duncan pada taraf nyata $5 \%$.

Hal tersebut diduga, setek jambu air untuk mengeluarkan tunas ditentukan oleh faktor dalam setek. Dalam setek mengandung cadangan makanan dan hormon endogen yang cukup menjamin tumbuhnya tunas. Menurut Achmad (2016), tumbuhnya tunas disebabkan oleh faktor tanaman seperti cadangan makanan pada batang setek dan faktor lingkungan yang optimum yaitu suhu dan kelembaban.

\section{Jumlah Tunas}

Terdapat interaksi antara konsetrasi urin sapi dengan lama perendaman terhadap jumlah tunas (Tabel 3). 
Tabel 3. Pengaruh konsentrasi dan lama perendaman urine sapi terhadap jumlah tunas (helai) umur 35 hst, 49 hst, dan 63 hst

\begin{tabular}{|c|c|c|c|c|}
\hline & & erendaman & & \\
\hline Konsentrasi & $\begin{array}{c}\mathrm{p}_{\mathrm{o}} \\
(0 \text { menit })\end{array}$ & $\begin{array}{c}\mathrm{p}_{1} \\
\text { (60 menit) }\end{array}$ & $\begin{array}{c}\mathrm{p}_{2} \\
\text { (90 menit) }\end{array}$ & $\begin{array}{c}\mathrm{p}_{3} \\
\text { (120 menit) }\end{array}$ \\
\hline $\mathrm{a}_{0}(0 \%)$ & $3,05 \mathrm{a}$ & $3,85 \mathrm{a}$ & $3,90 \mathrm{ab}$ & $4,60 \mathrm{~b}$ \\
\hline & A & A & $\mathrm{AB}$ & B \\
\hline$a_{1}(30 \%)$ & $4,50 \mathrm{~b}$ & $3,80 \mathrm{a}$ & $3,70 \mathrm{a}$ & $4,10 \mathrm{a}$ \\
\hline & A & A & A & A \\
\hline $\mathrm{a}_{2}(50 \%)$ & $4,50 \mathrm{~b}$ & $6,05 \mathrm{~b}$ & $4,65 \mathrm{~b}$ & $4,30 \mathrm{ab}$ \\
\hline & A & B & A & A \\
\hline $\mathrm{a}_{3}(70 \%)$ & $\begin{array}{c}5,70 \mathrm{~b} \\
\mathrm{~B}\end{array}$ & $\begin{array}{c}3,80 \mathrm{a} \\
\mathrm{A}\end{array}$ & $\begin{array}{c}2,80 \mathrm{a} \\
\mathrm{A}\end{array}$ & $\begin{array}{c}3,00 \mathrm{a} \\
\mathrm{A}\end{array}$ \\
\hline umur 49 hst & & & & \\
\hline $\mathrm{a}_{0}(0 \%)$ & $2,40 \mathrm{a}$ & $3,40 \mathrm{a}$ & $3,50 \mathrm{ab}$ & $3,75 \mathrm{a}$ \\
\hline & A & A & A & A \\
\hline $\mathrm{a}_{1}(30 \%)$ & $4,35 \mathrm{~b}$ & $3,70 \mathrm{a}$ & $3,30 \mathrm{a}$ & $3,75 \mathrm{a}$ \\
\hline & A & A & A & A \\
\hline $\mathrm{a}_{2}(50 \%)$ & $3,95 \mathrm{~b}$ & $5,60 \mathrm{~b}$ & $4,35 \mathrm{~b}$ & $3,90 \mathrm{a}$ \\
\hline & A & B & $\mathrm{AB}$ & A \\
\hline $\mathrm{a}_{3}(70 \%)$ & $4,00 \mathrm{~b}$ & $2,91 \mathrm{a}$ & $2,45 \mathrm{a}$ & $2,90 \mathrm{a}$ \\
\hline & B & $\mathrm{AB}$ & A & A \\
\hline umur $63 \mathrm{hst}$ & & & & \\
\hline $\mathrm{a}_{0}(0 \%)$ & $2,25 \mathrm{a}$ & $3,40 \mathrm{a}$ & $3,65 \mathrm{~b}$ & $3,75 \mathrm{a}$ \\
\hline & A & A & B & B \\
\hline $\mathrm{a}_{1}(30 \%)$ & $4,40 \mathrm{~b}$ & $3,95 \mathrm{a}$ & $3,30 \mathrm{a}$ & $3,45 \mathrm{a}$ \\
\hline & A & A & A & A \\
\hline $\mathrm{a}_{2}(50 \%)$ & $4,05 \mathrm{~b}$ & $5,60 \mathrm{~b}$ & $4,35 \mathrm{~b}$ & $3,90 \mathrm{a}$ \\
\hline & A & B & $\mathrm{AB}$ & A \\
\hline$a_{3}(70 \%)$ & $4,00 \mathrm{~b}$ & $3,00 \mathrm{a}$ & $2,20 \mathrm{a}$ & $2,80 \mathrm{a}$ \\
\hline & B & $\mathrm{AB}$ & A & A \\
\hline
\end{tabular}

Keterangan : Angka yang diikuti huruf kecil yang sama arah vertikal dan huruf besar yang sama arah horizontal menunjukan berbeda tidak nyata menurut uji Jarak Berganda Duncan pada taraf nyata $5 \%$.

Pada Tabel 3 terlihat jumlah tunas pada perendaman setek dengan waktu yang lebih lama memungkinkan IAA dari larutan urine lebih bayak terserap ke dalam setek. Pada konsentrasi yang lebih pekat, jumlah IAA yang diserap lebih banyak menyebabkan pembusukan dan ditandai dengan warna kehitaman pada batang setek. Menurut Hasibuan (2018), penentuan konsentrasi tergantung dari lamanya bahan setek direndam dan jenis tanamannya, semakin lama perendaman semakin kecil konsentrasi yang diaplikasikan. Sesuai penelitian Gaol et al. (2017), perendaman yang terlalu lama pada setek dapat menyebabkan pembusukan dan ditandai dengan warna kehitaman. Pada lama perendaman 0 menit (setek hanya dicelupkan saja), dengan konsentrasi urine 
$30 \%, 50 \% 70 \%$ tidak berbeda nyata , tetapi berbeda nyata dengan konsentrasi $0 \%$ (berisi air saja) pada semua umur pengamatan.

Lama perendaman selama 60 menit dan 90 menit pada konsentrasi 50\% menghasilkan jumlah tunas lebih banyak dan berbeda nyata dibandingkan dengan konsentrasi lainnya. Perendaman setek selama 120 menit, menghasilkan jumlah tunas yang tidak berbeda pada berbagai konsentrasi, kecuali pada umur 35 hst. Pada umur ini, jumlah tunas lebih banyak pada lama perendaman 120 menit dengan konsentrasi $50 \%$ tapi tidak berbeda dengan $0 \%$.

\section{Panjang Tunas}

Tidak terdapat pengaruh interaksi antara konsentrasi urin sapi dengan lama perendaman terhadap panjang tunas. Secara mandiri konsentrasi urine sapi berpengaruh nyata terhadap panjang tunas, sedangkan lama perendaman tidak berpengaruh nyata terhadap panjang tunas (Tabel 4).

Tabel 4. Pengaruh konsentrasi dan lama perendaman urine sapi terhadap panjang tunas $(\mathrm{cm})$ Umur 35 hst, 49 hst, dan 63 hst

\begin{tabular}{|c|c|c|c|c|c|}
\hline \multicolumn{6}{|l|}{ Umur 35 hst } \\
\hline \multirow[b]{2}{*}{ Konsentrasi } & \multicolumn{4}{|c|}{ Lama Perendaman } & \multirow[t]{2}{*}{ Rata-rata } \\
\hline & $\begin{array}{l}\mathrm{p}_{\mathrm{o}} \\
(0)\end{array}$ & $\begin{array}{c}\mathrm{p}_{1} \\
\text { (60 menit) }\end{array}$ & $\begin{array}{c}\mathrm{p}_{2} \\
\text { (90 menit) }\end{array}$ & $\begin{array}{c}\mathrm{p}_{3} \\
\text { (120 menit) }\end{array}$ & \\
\hline $\mathrm{a}_{0}(0 \%)$ & 0,55 & 0,63 & 0,66 & 0,78 & $0,66 \mathrm{a}$ \\
\hline $\mathrm{a}_{1}(30 \%)$ & 0,93 & 1,43 & 1,20 & 0,94 & $1,13 \mathrm{~b}$ \\
\hline $\mathrm{a}_{2}(50 \%)$ & 0,93 & 1,72 & 1,02 & 0,98 & $1,16 \mathrm{c}$ \\
\hline $\mathrm{a}_{3}(70 \%)$ & 0,96 & 0,60 & 0,52 & 0,49 & $0,64 \mathrm{a}$ \\
\hline \multirow[t]{2}{*}{ Rata-rata } & 0,84 & 1,09 & 0,85 & 0,79 & \\
\hline & A & A & A & A & \\
\hline \multicolumn{6}{|l|}{ Umur 49 hst } \\
\hline $\mathrm{a}_{0}(0 \%)$ & 0,91 & 0,98 & 1,11 & 1,02 & $1,01 \mathrm{a}$ \\
\hline$a_{1}(30 \%)$ & 1,27 & 1,57 & 1,44 & 1,11 & $1,35 \mathrm{~b}$ \\
\hline $\mathrm{a}_{2}(50 \%)$ & 1,17 & 1,84 & 1,63 & 1,13 & $1,44 \mathrm{c}$ \\
\hline $\mathrm{a}_{3}(70 \%)$ & 0,96 & 0,80 & 0,93 & 0,87 & $0,89 \mathrm{a}$ \\
\hline Rata-rata & $\begin{array}{c}1,08 \\
\mathrm{~A}\end{array}$ & $\begin{array}{c}1,29 \\
\mathrm{~A}\end{array}$ & $\begin{array}{c}1,28 \\
\mathrm{~A}\end{array}$ & $\begin{array}{c}1,03 \\
\mathrm{~A}\end{array}$ & \\
\hline \multicolumn{6}{|l|}{ Umur $63 \mathrm{hst}$} \\
\hline $\mathrm{a}_{0}(0 \%)$ & 1,06 & 1,20 & 1,23 & 1,26 & $1,19 \mathrm{a}$ \\
\hline $\mathrm{a}_{1}(30 \%)$ & 1,33 & 1,06 & 1,51 & 1,20 & $1,28 \mathrm{a}$ \\
\hline $\mathrm{a}_{2}(50 \%)$ & 1,27 & 2,22 & 1,71 & 1,22 & $1,62 \mathrm{~b}$ \\
\hline $\mathrm{a}_{3}(70 \%)$ & 1,25 & 0,91 & 1,22 & 1,03 & $1,10 \mathrm{a}$ \\
\hline Rata-rata & $\begin{array}{c}1,23 \\
\mathrm{~A}\end{array}$ & $\begin{array}{c}1,35 \\
\mathrm{~A}\end{array}$ & $\begin{array}{c}1,42 \\
\mathrm{~A}\end{array}$ & $\begin{array}{c}1,18 \\
\mathrm{~A}\end{array}$ & \\
\hline
\end{tabular}

Keterangan : Angka yang diikuti huruf kecil yang sama arah vertikal dan huruf besar yang sama arah horizontal menunjukan berbeda tidak nyata menurut uji Jarak Berganda Duncan pada taraf nyata $5 \%$.

Pada Tabel 4 terlihat perlakuan konsentrasi $50 \%$ menghasilkan panjang tunas terpanjang pada semua umur pengamatan. Urine sapi mengandung Auksin dan Giberellin pada konsentrasi optimal dapat mempercepat terjadinya proses 
fisiologis yang menyebabkan pembelahan sel menjadi lebih cepat. Sejalan dengan pendapat Adnan et al. (2017), bahwa pemberian ZPT dengan konsentrasi rendah tidak akan menunjukkan perubahan yang signifikan pada tanaman, sedangkan pemberian pada konsentrasi yang terlalu tinggi pertumbuhan tunas terhambat.

\section{Luas Daun dan Panjang Akar}

Tidak terdapat pengaruh interaksi antara konsentrasi urin sapi dengan lama perendaman terhadap luas daun dan panjang akar. Demikian pula secara mandiri konsentrasi urine sapi dan lama perendaman tidak berpengaruh nyata terhadap luas daun dan panjang akar (Tabel 5).
Luas daun lebih berkaitan dengan panjang akar dan volume akar. Tanaman yang memiliki akar pendek akan membatasi penyerapan unsur hara, sehingga kurang bahan untuk melakukan proses metabolisme sel termasuk memperluas daun. Walaupun setek direndam larutan urine sapi sampai 120 menit dengan konsentrasi $70 \%$, jumlah ZPT yang terserap oleh setek belum mampu mendorong untuk memperbesar ukuran sel sel daun. Pada percobaan di lapangan setek sengaja ditumbuhkan pada naungan dengan intensitas cahaya rendah, menyebabkan akar yang tumbuh pendek-pendek.

Tabel 5. Pengaruh konsentrasi dan lama perendaman urine sapi terhadap luas daun dan panjang

\begin{tabular}{|c|c|c|c|c|c|}
\hline \multicolumn{6}{|c|}{ Luas daun $\left(\mathrm{cm}^{2}\right)$} \\
\hline \multirow[t]{2}{*}{ Konsentrasi } & \multicolumn{4}{|c|}{ Lama perendaman } & \multirow[t]{2}{*}{ Rata-rata } \\
\hline & $\begin{array}{l}\mathrm{p}_{\mathrm{o}} \\
(0)\end{array}$ & $\begin{array}{c}\mathrm{p}_{1} \\
\text { (60 menit) } \\
\end{array}$ & $\begin{array}{c}\mathrm{p}_{2} \\
\text { (90 menit) }\end{array}$ & $\begin{array}{c}\mathrm{p}_{3} \\
\text { (120 menit) }\end{array}$ & \\
\hline $\mathrm{a}_{0}(0 \%)$ & 135,10 & 176,29 & 208,04 & 140,35 & $164,94 \mathrm{a}$ \\
\hline $\mathrm{a}_{1}(30 \%)$ & 166,71 & 182,00 & 217,65 & 180,11 & $186,61 \mathrm{a}$ \\
\hline $\mathrm{a}_{2}(50 \%)$ & 158,62 & 265,16 & 252,91 & 106,61 & $195,82 \mathrm{a}$ \\
\hline \multirow[t]{2}{*}{$a_{3}(70 \%)$} & 170,24 & 102,93 & 149,73 & 239,68 & $165,64 \mathrm{a}$ \\
\hline & 157,67 & 181,59 & 207,082 & 166,68 & \\
\hline Rata-rata & A & A & A & $\mathrm{A}$ & \\
\hline \multicolumn{6}{|c|}{ Panjang akar $(\mathrm{cm})$} \\
\hline & Po & $\mathrm{p} 1$ & $\mathrm{p} 2$ & p3 & \\
\hline $\mathrm{a} 0$ & 8,85 & 7,90 & 8,15 & 8,00 & 8,23 a \\
\hline a1 & 9,50 & 9,85 & 11,5 & 8,05 & $9,73 \mathrm{a}$ \\
\hline $\mathrm{a} 2$ & 9,60 & 12,75 & 9,25 & 7,20 & $9,70 \mathrm{a}$ \\
\hline a3 & 8,15 & 7,95 & 7,30 & 7,85 & $7,81 \mathrm{a}$ \\
\hline Rata-rata & 9,03 & 9,61 & 9,05 & 7,78 & \\
\hline & A & A & A & A & \\
\hline
\end{tabular}

Keterangan : Angka yang diikuti huruf kecil yang sama arah vertikal dan huruf besar yang sama arah horizontal menunjukan berbeda tidak nyata menurut uji Jarak Berganda Duncan pada taraf nyata $5 \%$

Menurut Sri Haryanti (2008), tanaman yang tumbuh pada lingkungan cahaya berintensitas rendah memiliki akar lebih kecil jumlahnya sedikit antar sel dan tersusun dari sel berdinding tipis.

\section{SIMPULAN}

1.Terdapat pengaruh interaksi antara konsentrasi urine sapi dengan lama perendaman terhadap jumlah tunas setek 
jambu air, sedangkan terhadap kecepatan tumbuh, panjang tunas, luas daun dan panjang akar tidak berpengaruh.

2. Perendaman setek jambu air selama 60 menit dalam larutan urine sapi dengan konsentrasi $50 \%$ menghasilkan jumlah tunas paling banyak yaitu 5,6 tunas.

\section{DAFTAR PUSTAKA}

Harahap, A. K Z. (2017) Analisis perilaku konsumen terhadap hasil produksi jambu mau usaha Raisyah desa Aek Tuhul kecamatan Padang Sisimpuan Batunadua kota Padangsidimpuan, Jurnal LPPM UGN. 7 (3) Maret 2017.

Achmad, B. (2016). Efektivitas rootone-f, air kelapa muda dan ekstrak bawang merah dalam merangsang pertumbuhan setek batang pasak bumi. Jurnal Hujan Tropis. 4 (3).

Adnan, B. R. Juanda, dan M. Zaini. (2017). Pengaruh konsentrasi dan lama perendaman dalam zpt auksin terhadap viabilitas benih semangka (citurullus lunatus) kadaluarsa. Jurnal Agrosamudra, 4(1), 45-57

Anggrawati, P. S., dan Z.M Ramadhana (2016). Kandungan senyawa kimia dan bioaktivitas dari jambu air (Syzygium aqueum Burn.f.Alston). Farmaka, 14, 417-433

Aprilia, Jelita Zahra, Wisanti Wisanti, Eva Kristinawati Putri. (2001). Kajian taksonomi numerik tiga jenis syzygium berdasarkan karakter morfologi. Lenterabio, 10(1), 40-50. https://journal.unesa.ac.id/index. php/lenterabio/index

Danu, A.S, dan A.Z. Abidin. (2011). pengaruh umur pohon induk terhadap perakaran stek nyamplung (Calophyllum inophyllum L). Jurnal Penelitian Hutan Tanaman, 8(1), 41-49
Disperta Madiun. (2021). 10 Jenis ambu air, https://disperta.madiunkota.go.id/2021/02 /13/10-jenis-jambu-air/

Fanesa, A. 2011. Pengaruh Pemberian Beberapa Zat Pengatur Tumbuh terhadap Pertumbuhan Setek Pucuk Jeruk Kacang (Citrus nobilis). Skripsi. program studi Agroteknologi Fakultas Pertanian Universitas Andalas, Padang

Gaol, N.L, C.L. Kaunang, dan R.F. Dompas. (2017). Pengaruh konsentrasi dan lama perendaman a.pintoi dengan urine ternak sapi terhadap pertumbuhan tanaman a.pintoi. Jurnal Zootek, 37(2), 15-24.

Hadi EP, Y. Widiawati dan Sukarsa. (2012). Keanekaragaman dan kekerabatan Syzygiumaksesi Purwokerto. Biosfera, 29 (1), 42-50

Hardiansyah, J. 2018. Pengaruh Lama Perendaman dari Berbagai ZPT terhadap Pertumbuhan Stek Batang Jeruk Nipis (Citrus aurantifolia swingle). Skripsi. Fakultas Pertanian Universitas Muhammadiyah, Sumatera Utara

Hariani, F, Suryawaty, dan M.L. Arunasi. (2018) . Pengaruh beberapa zat pengatur tumbuh alami dengan lama perendaman terhadap pertumbuhan stek jeruk nipis (Citrus aurantifolia swingle). Jurnal Agrium, 21 (2).

Hasibuan, R.J. 2018. Beberapa Ekstrak Tanaman sebagai ZPT Alami dan Lama Perendaman Meningkatkan Pertumbuhan Stek Tanaman Mucuna bracteata. Skripsi. Program studi Agroteknologi Fakultas Pertanian Universitas Muhammadiyah Sumatera Utara, Medan.

Mulyani, C dan J. Ismail. (2015). Pengaruh konsentrasi dan lama perendaman rootone $\mathrm{F}$ terhadap pertumbuhan stek pucuk jambu air (syzygium semarangense) pada media oasis. Jurnal Penelitian Agrosamudra, 2 (2) JuliDesember 2015 
Mulyani, I.S, A.A. Fatmawaty, dan S. Ritawati. (2018). Pengaruh pemberian tingkat konsentrasi larutan fermentasi urine sapi dan lama perendaman terhadap perkecambahan benih trembesi (Samanea saman). Jurnal Agroekotek, 10(2), 73-80

Pradani, I.C, H. Rianto, dan Y.E. Susilawati. (2018). Pengaruh macam bahan stek dan konsentrasi filtrat bawang merah (allium cepa fa. ascalonicum, 1.) terhadap pertumbuhan bibit jambu air (Syzygium aqueum, Burm) Varietas Citra. Jurnal Ilmu Pertanian Tropika dan Subtropika . 4(1), 24-28.

Rebin. 2013. Teknik perbanyakan jambu air citra melalui setek cabang. Balai Penelitian Tanaman Buah Tropika. Sumatera Barat. Padang htps://hortikultura.litbang.pertanian.go.id /publikasi-detail-IPTEK2013.html

Santoso, N.I. 2017. Pengaruh Hormon Alami dengan Tingkat Konsentrasi dan
Lama Perendaman terhadap Pertumbuhan Setek Batang Tanaman Tin (Ficus carica L.) Skripsi. Fakultas Pertanian Universitas Muhammadiyah Gresik, Gresik.

Sri Haryanti. (2010). Pengaruh naungan yang berbeda terhadap jumlah stomata dan ukuran porus sotamata daun Zephyranthes Rosea Lindl, Buletin Anatomi dan Fisiologi. XVIII (1), Maret 2010

https://media.neliti.com/media/publicatio ns/59917-ID

Yunanda, J, Murniati, dan S. Yoseva. (2015). Pertumbuhan stek batang tanaman buah naga (Hylocereus costaricensis) dengan pemberian beberapa konsentrasi urine sapi. Jurnal JOM Faperta. 2. (1). 